\title{
Utilization of Plastic Waste Polyethylene (PET) for reinforced subgrade
}

\author{
Roberth Evander Meidudga ${ }^{1}$, Fikri Faris ${ }^{1 *}$, Hary Christady Hardiyatmo ${ }^{1}$, and Afif Agri Diansyah ${ }^{1}$ \\ ${ }^{1}$ Department of Civil Engineering and Environmental, Gadjah Mada University, Indonesia
}

\begin{abstract}
Plastic waste is a serious problem for the survival of all creatures on Earth. Recycling is one solution to reduce the negative impact of environmental pollution caused by plastic waste. A lot of plastic waste that pollutes the Earth comes from plastic bottle waste (PET). There had been many studies that discussed the use of plastic bottle waste (PET); however, this research used the plastic bottle waste (PET) as a geocell for subgrade reinforcement. To this date, the use of plastic bottle waste as geocell is still rare. The main purpose of this study was to determine the effect of adding geocell of plastic bottle waste on the subgrade using a capping layer that had a low bearing capacity. This research was expected to reduce the impact of environmental pollution due to plastic bottle waste, and be an alternative solution for additional reinforcement in the capping layer. Therefore, it could increase the ultimate bearing capacity and reduce the thickness of the cover layer on subgrades that had a CBR value below 5\%. The results of the analysis using the Plaxis program showed that the geocell from plastic bottle waste could be used to save the use of capping layer materials by up to $65 \%$.
\end{abstract}

\section{Introduction}

Between 1950 and the present, about 6.3 billion tons of plastic waste have been generated worldwide. As the human population grows, the demand for products that use plastic also increases. Recently, plastic waste production reaches 380 million tons per year. The disposal of plastic into the environment has had a negative impact, one of which is on international waters [1].

Indonesia still has problems with waste management, second worst in the world after China. Previous studies on plastic waste that pollute the environment show that Indonesia is responsible for $15 \%$ of plastic waste in global waters [2]. One type of plastic waste that is widely circulated and hurts the environment is Polyethylene Terephthalate (PET). This type of plastic is plastic with code 1 . Its use as a primary material for packaging bottles reaches $30 \%$ of the world use [3].

Research and development of cellular (geocell) confinement system began with the U.S. Army Corps of Engineering in September 1975 to test the feasibility of contructing tactical bridge approach roads over soft ground [4]. Geocell made of geosynthetics such as geotextiles or geogrids, are thermally welded or mechanically bonded interconnected pocket structures in the form of mattresses used with in-filled soil. General reinforcing mechanisms of geocell is confining the in-fill soil from shearing away and derive anchorage resistance through the surrounding soil against the applied load [5]. The geocell mattress consists of a series of interlocking cell constructed from polymer. The more recent advancement of reinforcement of reinforced soil is to provide three-dimensional confinement to the soil using geocells. The geocell foundation mattress consists of a series of the interlocking cell constructed from polymer geogrids, which contains and confines the soil within its pockets. It intercepts the potential failure planes because of its rigidity and forces them deeper into foundation soil, thereby increasing the bearing capacity of the soil []․ In pavement and road construction, the effect of geocellreinforced recycled asphalt pavement (RAP) bases over weak subgrade under cyclic plate loading and found that geocell has improved the performance of RAP bases over weak subgrade as compared with the unreinforced base section and geocell significantly increased the percentage of resilient deformation of the RAP base. The geocell reinforcement reduced the vertical stresses transferred to the subgrade by distributing the load over a wider area [7]. The bearing capacity improvement of gravel base layer in road constructions using geocell and concluded that geocell layer placed within the gravel base layer of asphalt paved construction reduced the vertical stresses on subgrade during vehicle crossing about $30 \%$ and increased the layer modulus of the gravel base layers compared to an unreinforced layer. As a result, the measured deflections on the asphalt surface were also reduced [8].

Transforming plastic bottle waste (PET) into geocell is a solution to overcome the existing plastic waste issue. Considering the enormous potential in the use of PETtype plastic (mineral water bottles), this study focused on the use of plastic bottle waste (PET) as a subgrade reinforcement. Plastic bottle waste planted under a road layer that resembles a geocell is expected to increase the ultimate bearing capacity of the subgrade to stabilize the subgrade and minimize the settlement. 

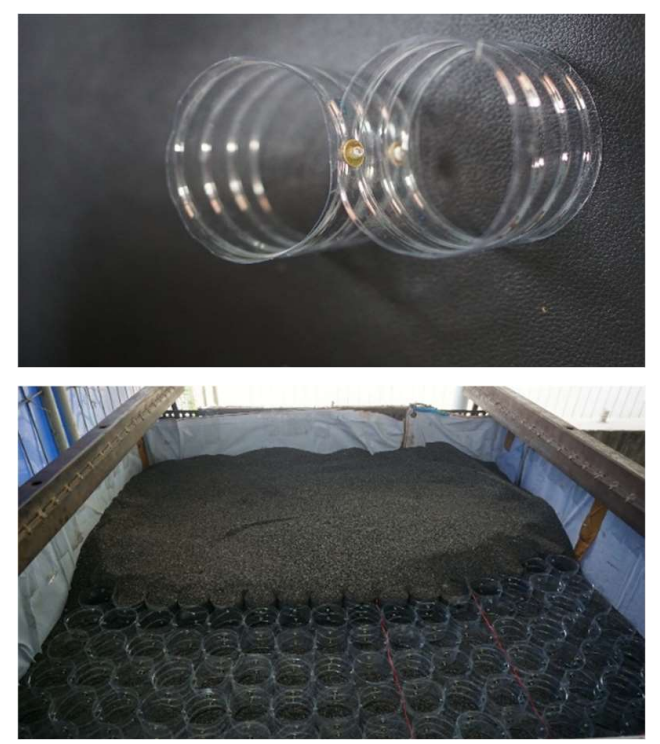

Fig. 1. Geocell plastic bottle waste

The geocell used in this study was a geocell made from PET plastic bottle waste $(600 \mathrm{ml}$ mineral water bottle). The bottle was cut into two height variations, $50 \mathrm{~mm}$ and $75 \mathrm{~mm}$, then the pieces of the bottle were joined by using a blind rivet measuring $2.4 \mathrm{~mm} \times 6 \mathrm{~mm}$ in a square shape. Figure 1 shows the geocell of the assembled PET plastic bottle waste.

\section{Experimental methods}

\subsection{Plate load test}

Laboratory scale plate load, test was carried out according to ASTM D-1194, and by adding a plastic bottle waste geocell to the subgrade [9].

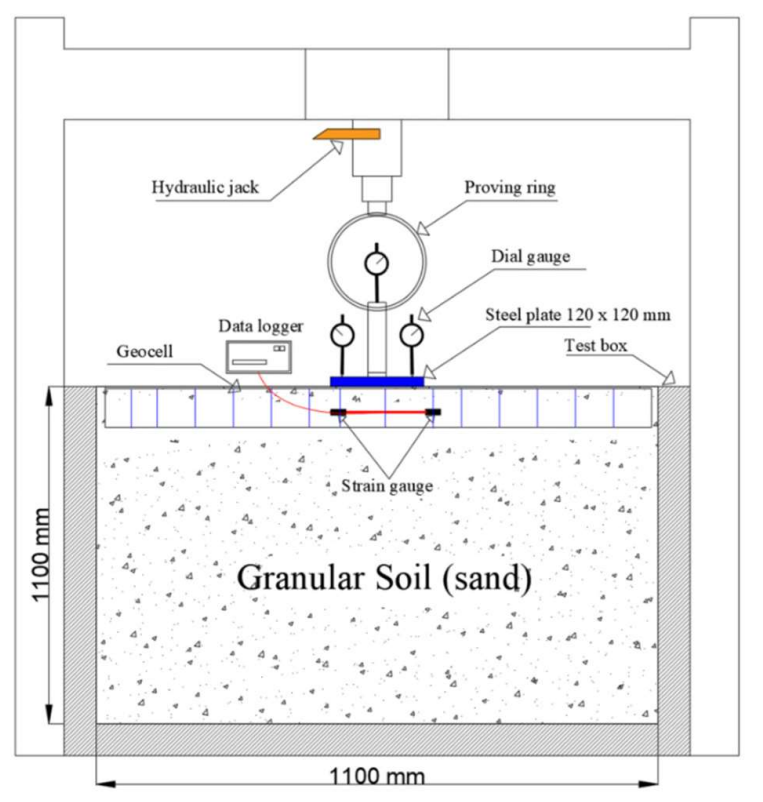

Fig. 2. Schematic view of the test setup.

The test was conducted in the laboratory of the Department of Civil and Environmental Engineering,
Gadjah Mada University. The loading test was conducted to determine the ultimate soil bearing capacity and the settlement at the laboratory scale. In this case, maximum soil holding capacity and settlement with geocell reinforcement and without reinforcement from bottle waste. The subgrade used during laboratory testing was sand with a classification (USCS) SP (poorly graded sand) Friction angle $\phi=32^{\circ}$ and Cohesion, $c=0 \mathrm{kN} / \mathrm{m}^{2}$. The loading test results are presented in Table 1.

The ultimate bearing capacity is defined as the maximum load per unit area where the soil can still support the load without collapsing, which is expressed in the following equation [10].

$$
q_{u}=\frac{P_{u}}{A}
$$

in which $q u$ is the ultimate bearing capacity $\left(\mathrm{kN} / \mathrm{m}^{2}\right), P u$ is the maximum load $(\mathrm{kN})$, and $A$ is the plate area or foundation $\left(\mathrm{m}^{2}\right)$.

Bearing capacity ratio (BCR) is the ratio of the carrying capacity value in the presence of geosynthetic materials or geocells from PET plastic bottle waste and the carrying capacity values without geosynthetic material or geocell from PET bottle. The equation for the bearing capacity ratio $(\mathrm{BCR})$ is as follows [11].

$$
B C R=\frac{q_{r}}{q_{o}}
$$

in which BCR is the bearing capacity ratio, $q_{r}$ is the bearing capacity value in the presence of geosynthetic reinforcement $\left(\mathrm{kN} / \mathrm{m}^{2}\right)$, and $q_{o}$ is the bearing capacity value without geosynthetic reinforcement $\left(\mathrm{kN} / \mathrm{m}^{2}\right)$.

Table 1. The results of the bearing capacity of the soil and its

\begin{tabular}{|c|c|c|}
\hline $\begin{array}{c}\text { Variation of loading } \\
\text { test }\end{array}$ & $\begin{array}{c}\text { Ultimate soil } \\
\text { bearing capacity } \\
\left(\mathrm{kN} / \mathrm{m}^{2}\right)\end{array}$ & $\begin{array}{c}\text { Settlement } \\
(\mathrm{mm})\end{array}$ \\
\hline Unreinforced & 416,67 & 8,93 \\
\hline $\begin{array}{c}\text { Reinforced geocell } 50 \\
\mathrm{~mm}\end{array}$ & 1111,11 & 17,59 \\
\hline $\begin{array}{c}\text { Reinforced geocell } 75 \\
\mathrm{~mm}\end{array}$ & 1250 & 15,153 \\
\hline
\end{tabular}

The results of the loading test in the laboratory can be seen in Table 1. It shows that the increase in the ultimate soil bearing capacity increased when geocells were added from plastic bottle waste. The average increase in the carrying capacity of the soil after adding the geocell reinforcement of plastic bottle waste was $183.82 \%$. The bearing capacity ratio (BCR) value on average increased to 2.94 . 
Table 2. The results of soil bearing capacity and its settlement

\begin{tabular}{|c|c|c|}
\hline $\begin{array}{c}\text { Variation of loading } \\
\text { test }\end{array}$ & $\begin{array}{c}\text { Soil bearing } \\
\text { capacity } \\
\left(\mathrm{kN} / \mathrm{m}^{2}\right)\end{array}$ & $\begin{array}{c}\text { Settlement } \\
(\mathrm{mm})\end{array}$ \\
\hline Unreinforced & 416,67 & 8,93 \\
\hline $\begin{array}{c}\text { Reinforced geocell 50 } \\
\mathrm{mm}\end{array}$ & 416,67 & 3,01 \\
\hline $\begin{array}{c}\text { Reinforced geocell 75 } \\
\mathrm{mm}\end{array}$ & 416,67 & 3,035 \\
\hline
\end{tabular}

It can be seen in Table 2 that the percentage of settlement experienced a decline if given the similar load of about $416.67 \mathrm{kN} / \mathrm{m}^{2}$ for each variation of the loading test. The decrease without reinforcement was 8.93 or $100 \%$ to $3.0225 \mathrm{~mm}$ or $33.85 \%$. This decrease proves that the geocell from plastic bottle waste can affect the characteristics of sandy soil by increasing the bearing capacity and declining the settlement.

The increase in soil-bearing capacity and settlement is affected by the height of the geocell and locking of the sandy soil in the geocell structure, thus, there is no excessive lateral force on the sand. The increase in the ultimate bearing capacity occurred when a $75 \mathrm{~mm}$ geocell was used. This is because the area to accommodate and lock the sandy soil in the geocell is slightly wider. This condition reduces the lateral forces of the sandy soil caused by the load on it.

\subsection{Tensile strength test}

After the loading test was conducted, a tensile test was also carried out for the plastic bottle material using the ASTM E8 reference using universal testing machine (UTM). After testing the tensile material on 9 samples, the average working force was $101.59 \mathrm{~N}$ with the maximum strain of $3.79 \mathrm{~mm}$ or $37.97 \%$ of the original form.

From the results, an approach was conducted by using an equation referred to previous studies [12], which defines geocells as a composite material or plate with the following equation,

$$
E_{g}=4\left(\sigma_{3}\right)^{0,7}\left(K e+200 M^{0,16}\right)
$$

in which $E_{g}$ is the young's modulus of the geocellreinforced soil, $\sigma_{3}$ is the average horizontal stress at the mid-height of the geocell layer, $\mathrm{Ke}$ is the young's modulus parameter of the unreinforced soil and $M$ is the line of intersection of the geocell material modulus.

The geocell connection test (blind rivet) was carried out simply by giving the load gradually on three plastic bottles that had been cut and hung. The previously mentioned load was by increasing load of $1 \mathrm{~kg}$ per $30 \mathrm{sec}$ on the hung geocell until it failed at the connection or broke. From the results of 30 samples tested for connection, the average load that could be held by the connection on this PET bottle waste geocell was $14.56 \mathrm{~kg}$. The geocell connection test is presented in Figure 3.

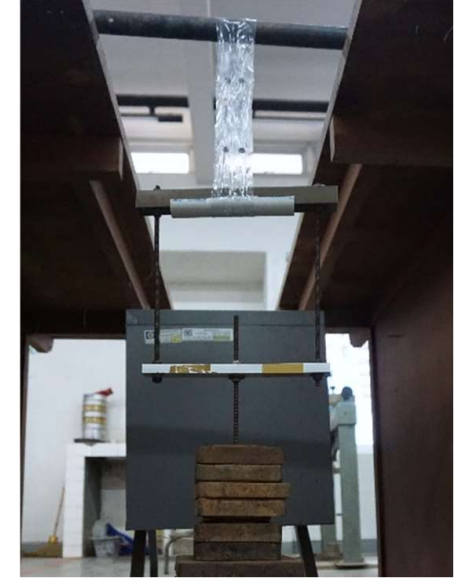

Fig. 3. Geocell connection test (blind rivet).

After trial and error in the Plaxis program, the values obtained were $E_{g}=107259 \mathrm{kN} / \mathrm{m}, E_{g} A=5362.96 \mathrm{kN} / \mathrm{m}$, and $E 1=1.117 \mathrm{kN} / \mathrm{m}^{2}$. These values were used in the material input parameter that defined the geocell material as a plate in the Plaxis 8.6 program.

\subsection{Subgrade analysis with Plaxis 8.6 program}

The subgrade analysed in this study was a subgrade with a CBR value below 5\%. One example is silt (lanau) which was given special treatment by increasing the thickness of the capping layer (granular soil) — classified by USCS as sand with poor grade or SP - of $300 \mathrm{~mm}$ to stabilize the above pavement [13].

\subsubsection{Traffic load input parameters on Plaxis}

The traffic load used the "D" load intensity, with uniform load (BTR) $q=9 \mathrm{kN} / \mathrm{m}^{2}$ on the entire body of the road, as referred to [14].

\subsubsection{Soil input parameters on Plaxis}

The soil parameter included in the Plaxis was silt soil. The material model used in this research was Mohr-Coulomb. In accordance with the results of the soil study, there was attempt to input the following silt (lanau) parameters in the Plaxis program.

$$
\begin{array}{ll}
\gamma_{\text {unsat }}=15\left(\mathrm{kN} / \mathrm{m}^{3}\right) & v=0,30 \quad \psi=0\left(^{\circ}\right) \\
\gamma_{\text {sat }}=18\left(\mathrm{kN} / \mathrm{m}^{3}\right) & c=40\left(\mathrm{kN} / \mathrm{m}^{2}\right) \\
\phi=10\left({ }^{\circ}\right) & E=3000\left(\mathrm{kN} / \mathrm{m}^{2}\right)
\end{array}
$$

The above parameters were used for the input of soil material on the silt (drained) subgrade. The parameters of the soil on the road layer and the overburden layer above the subgrade refer to [15].

\subsubsection{Geocell input parameters on Plaxis (plate)}

$$
\begin{array}{ll}
E A=5362,960 \mathrm{kN} / \mathrm{m} & w=0,850 \mathrm{kN} / \mathrm{m} \\
E I=1,117 \mathrm{kN} / \mathrm{m}^{2} & v=0,250 \\
d=0,050 \mathrm{~m} &
\end{array}
$$




\begin{tabular}{|c|}
\hline AC WC $: 40 \mathrm{~mm}$ \\
\hline AC BC $: 60 \mathrm{~mm}$ \\
\hline AC BASE $: 170 \mathrm{~mm}$ \\
\hline AGREGAT A $: 300 \mathrm{~mm}$ \\
\hline AGREGAT B $: 300 \mathrm{~mm}$ \\
\hline SUBGRADE (SILT) \\
\hline
\end{tabular}

Fig. 4. Road layer.

\section{Result and discussion}

\subsection{Total displacements (Extream $U_{\text {tot }}$ )}

A comparison of the settlement that occurred in the subgrade before and after the installation of geocells from plastic bottle waste can be seen in Figure 4 and Figure 5. It was found that the geocell from the plastic bottle waste can reduce the settlement due to the load above the subgrade up to $15,27 \mathrm{~mm}$ or $57,26 \%$ of the total settlement without geocell reinforcement. The largest settlement reduction was occurred in the middle part of the loading area. The reduction effect was confirmed by both plane strain and axisymmetric model by using Plaxis FEM software.
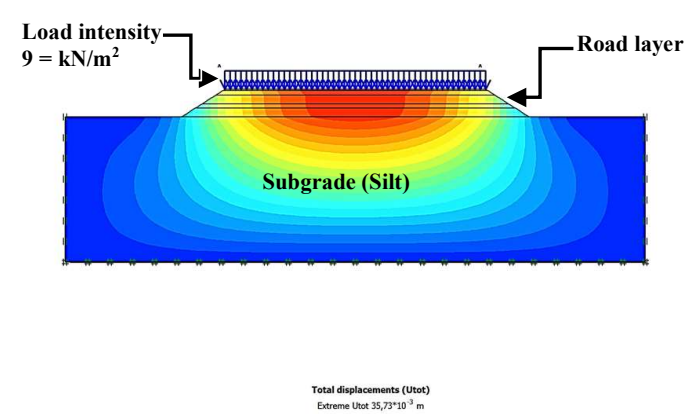

Fig. 5. Extreme $U_{\text {tot }}$ unreinforced geocell plane-strain $\left(35,73^{*} 10^{-3} \mathrm{~m}\right)$.
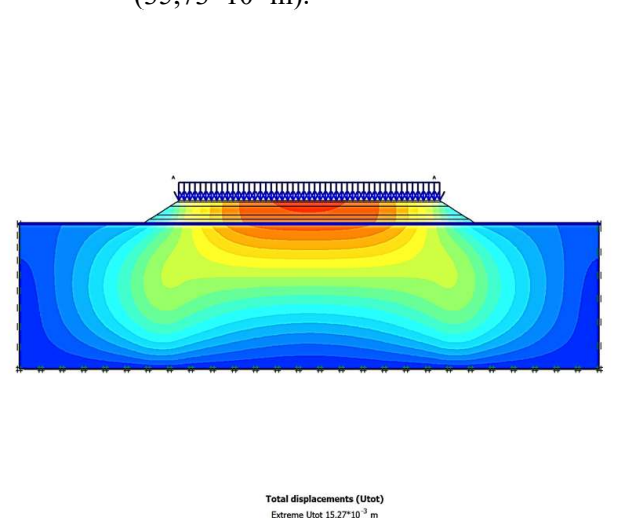

Fig. 6. Extreme $U_{\text {tot }}$ reinforced geocell plane-strain $\left(15,27 * 10^{-}\right.$ $\left.{ }^{3} \mathrm{~m}\right)$.
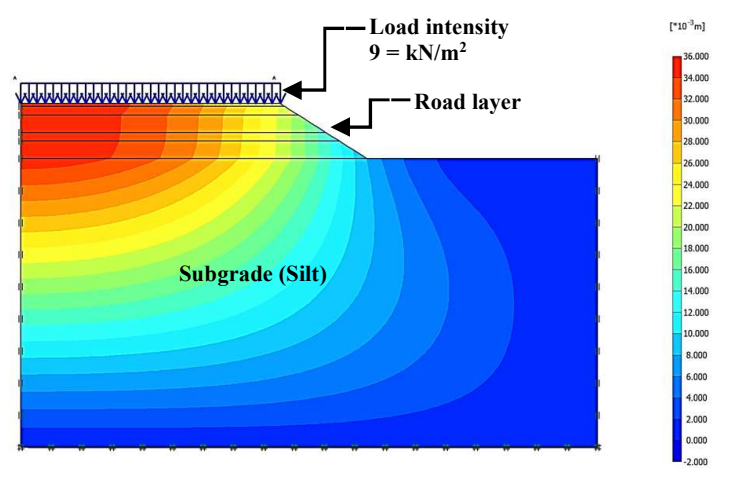

Fig. 7. Extreme $U_{\text {tot }}$ unreinforced geocell axisymmetry $\left(35,94 * 10^{-3} \mathrm{~m}\right)$.
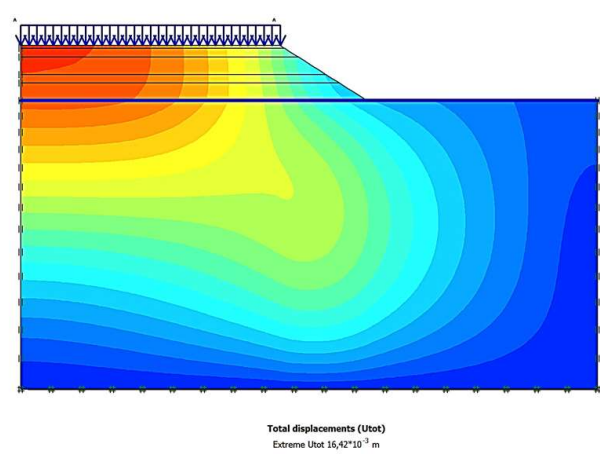

Fig. 8. Extreme $\mathrm{U}_{\text {tot }}$ reinforced geocell axisymmetry $\left(16,42 * 10^{-}\right.$ $\left.{ }^{3} \mathrm{~m}\right)$.

\subsection{Ultimate bearing capacity}

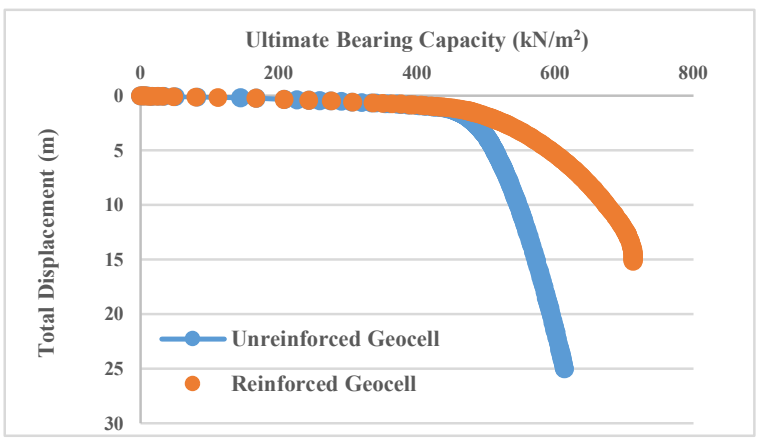

Fig. 9. Curve ultimate bearing capacity Plaxis $300 \mathrm{~mm}$ capping layer.

In Figure 9 the total displacements that occurred were more than $25 \mathrm{~mm}$. This is because in order to obtain the ultimate bearing capacity value in the Plaxis program, the subgrade must receive as much load as possible until the subgrade collapses. A trial of uniform loading was carried out on the road body that tested at $1000 \mathrm{kN} / \mathrm{m}^{2}$. When the subgrade collapses, the comparison of the bearing capacity between the unreinforced geocell and the 
reinforced geocell can be seen as the result curve Plaxis in Figure 9. More details of the results curve ultimate bearing capacity capping layer of $300 \mathrm{~mm}$ are presented in Table 3.

Table 3. Result of curve Plaxis capping layer $300 \mathrm{~mm}$.

\begin{tabular}{|l|c|c|}
\hline \multicolumn{1}{|c|}{ Result Plaxis } & $\begin{array}{c}\text { Ultimate bearing capacity } \\
\left(\mathrm{kN} / \mathrm{m}^{2}\right)\end{array}$ & BCR \\
\hline $\begin{array}{l}\text { Unreinforced } \\
\text { geocell PET }\end{array}$ & 613,534 & 1 \\
\hline $\begin{array}{l}\text { Reinforced } \\
\text { geocell PET }\end{array}$ & 712,911 & 1,162 \\
\hline
\end{tabular}

The results of the ultimate bearing capacity on Plaxis had increased up to $16.2 \%$. These results prove an increase occurred when geocells were added to the subgrade. In addition, the results validate the results of the experiments in the laboratory (plate load test) where geocells from plastic bottle waste can increase bearing capacity and decline the settlement.

\subsection{Analysis of capping layer thickness efficiency}

In this analysis, we tried reducing the thickness of the capping layer material up to $50 \%$ followed by adding the geocell material from the plastic bottle waste. The purpose of the analysis was to observe the behaviour of the geocell when the capping layer thickness is only $50 \%$ $(150 \mathrm{~mm})$.

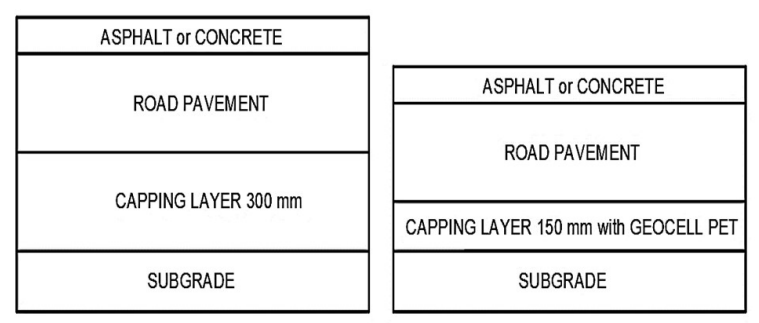

Fig. 10. Trial 50\% less capping layer.
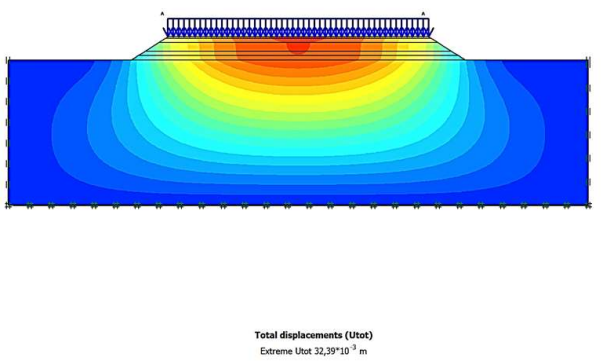

Fig. 11. Extreme $U_{\text {tot }}$ unreinforced geocell plane-strain $\left(32,39 * 10^{-3} \mathrm{~m}\right)$.

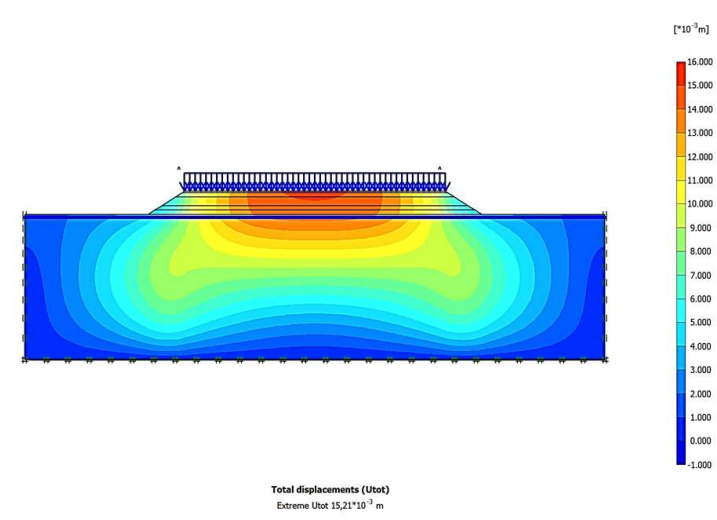

Fig. 12. Extreme $U_{\text {tot }}$ reinforced geocell plane-strain $\left(15,21 * 10^{-}\right.$ $\left.{ }^{3} \mathrm{~m}\right)$.

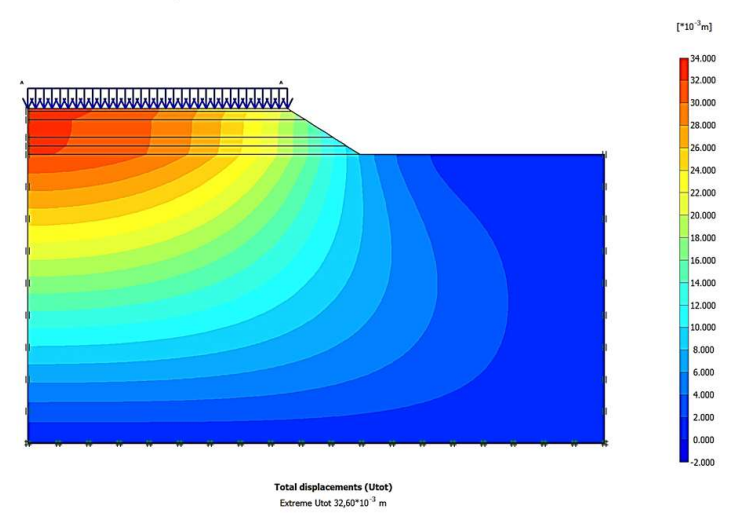

Fig. 13. Extreme $U_{\text {tot }}$ unreinforced geocell axisymmetry $\left(32,60 * 10^{-3} \mathrm{~m}\right)$.

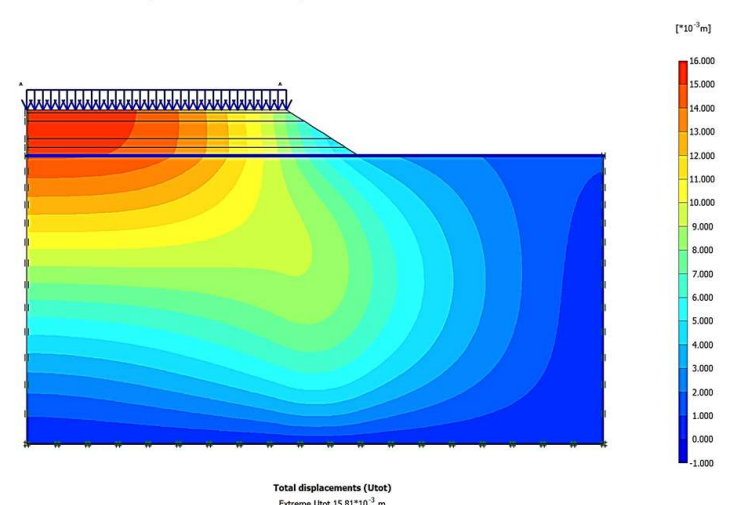

Fig. 14. Extreme $U_{\text {tot }}$ reinforced geocell axisymmetry $\left(15,81 * 10^{-3} \mathrm{~m}\right)$.

After the capping layer was reduced to $50 \%(150 \mathrm{~mm})$ by applying the same load when loading the capping layer of $300 \mathrm{~mm}$ above the road pavement, the geocell can reduce the settlement to $53,04 \%$ of the total settlement without geocell reinforcement. The results are shown in Figure 11 and Figure 12. 


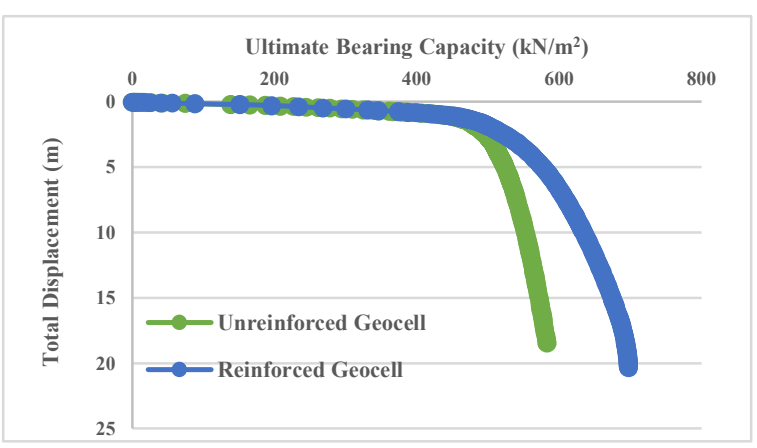

Fig. 15. Curve ultimate bearing capacity Plaxis 150 $\mathrm{mm}$ capping layer.

The results of the curve from the Plaxis program showed the ultimate bearing capacity behaviour with and without geocell reinforcement were relatively similar. This is due to there was only one parameter was made for the soil material and loading in the Plaxis program, with only the thickness of the capping layer that was different. The results of the $150 \mathrm{~mm}$ Plaxis capping layer curve are shown in Table 4.

Table 4. Result curve Plaxis capping layer $150 \mathrm{~mm}$

\begin{tabular}{|l|c|c|}
\hline \multicolumn{1}{|c|}{ Result Plaxis } & $\begin{array}{c}\text { Ultimate bearing capacity } \\
\left(\mathrm{kN} / \mathrm{m}^{2}\right)\end{array}$ & BCR \\
\hline $\begin{array}{l}\text { Unreinforced } \\
\text { geocell PET }\end{array}$ & 582,435 & 1 \\
\hline $\begin{array}{l}\text { Reinforced } \\
\text { geocell PET }\end{array}$ & 696,733 & 1,197 \\
\hline
\end{tabular}

The results of the Plaxis program in Table 4 show that the performance of geocell from plastic bottle waste could increase the bearing capacity of the soil up to $19.7 \%$ when the capping layer was reduced to $150 \mathrm{~mm}$.

Tried to reduce the capping layer with a thickness of 100 $\mathrm{mm}$ by Plaxis analysis

Fig. 16. Trial $65 \%$ less capping layer.

\begin{tabular}{|c|c|}
\hline ASPHALT Or CONCRETE & \multicolumn{1}{|c|}{ ASPHALT or CONCRETE } \\
ROAD PAVEMENT & ROAD PAVEMENT \\
\hline CAPPING LAYER $300 \mathrm{~mm}$ & CAPPING LAYER $100 \mathrm{~mm}$ with GEOCELL PET \\
\hline SUBGGRADE \\
\hline
\end{tabular}

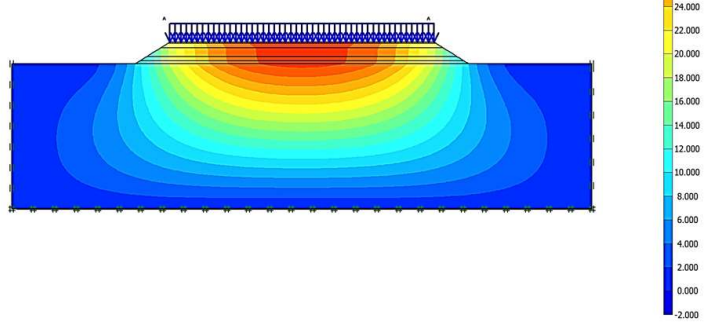

Fig. 17. Extreme $U_{\text {tot }}$ unreinforced geocell plane-strain $\left(31,31 * 10^{-3} \mathrm{~m}\right)$.

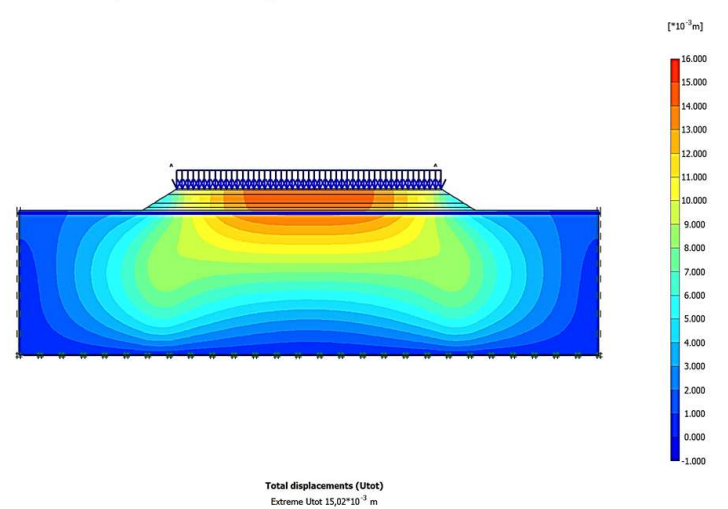

Fig. 18. Extreme $U_{\text {tot }}$ reinforced geocell planestrain $\left(15,02 * 10^{-3} \mathrm{~m}\right)$.

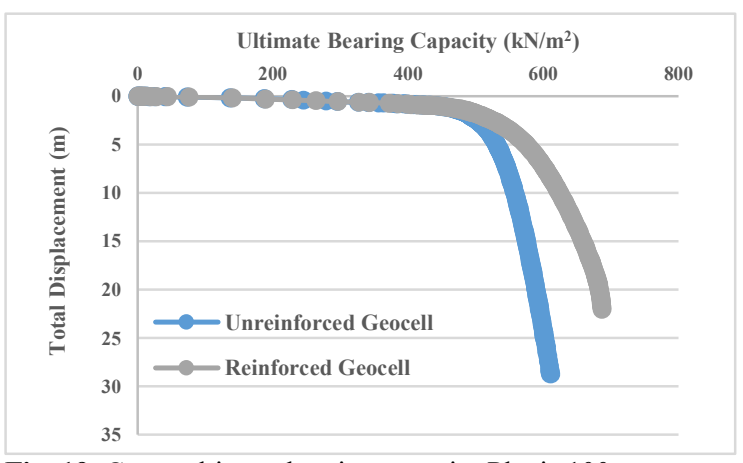

Fig. 19. Curve ultimate bearing capacity Plaxis 100 $\mathrm{mm}$ capping layer.

Table 5. Result curve Plaxis capping layer $150 \mathrm{~mm}$.

\begin{tabular}{|l|c|c|}
\hline \multicolumn{1}{|c|}{ Result Plaxis } & $\begin{array}{c}\text { Ultimate bearing capacity } \\
\left(\mathrm{kN} / \mathrm{m}^{2}\right)\end{array}$ & BCR \\
\hline $\begin{array}{l}\text { Unreinforced } \\
\text { geocell PET }\end{array}$ & 610,818 & 1 \\
\hline $\begin{array}{l}\text { Reinforced } \\
\text { geocell PET }\end{array}$ & 686,784 & 1,197 \\
\hline
\end{tabular}

The results of the Plaxis program in Figure 19 show that the performance of geocell from plastic bottle waste could increase the bearing capacity of the soil up to $11,94 \%$ when the capping layer was reduced to $100 \mathrm{~mm}$. 


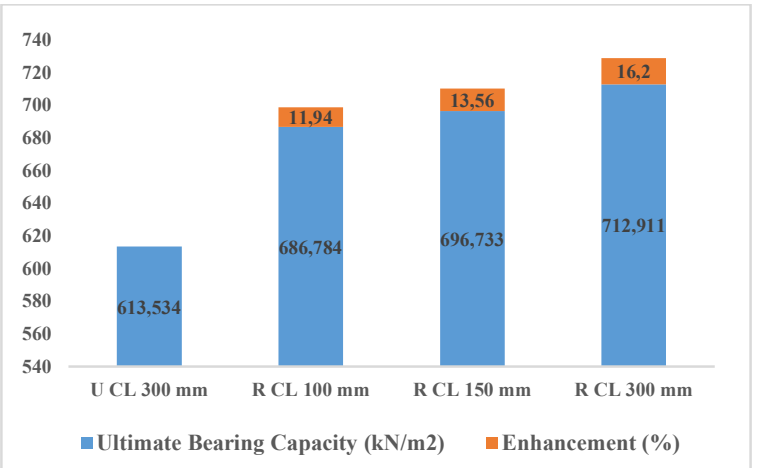

Fig. 20. Percentage on ultimate bearing capacity increase with capping layer of $100 \mathrm{~mm}, 150 \mathrm{~mm}$, and $300 \mathrm{~mm}$.

The percentage comparison of ultimate bearing capacity when unreinforced capping layer $300 \mathrm{~mm}$ (U CL $300 \mathrm{~mm}$ ), reinforced capping layer $100 \mathrm{~mm}$ (R CL 100 $\mathrm{mm})$, reinforced capping layer $150 \mathrm{~mm}$ (R CL $150 \mathrm{~mm}$ ), and reinforced capping layer $300 \mathrm{~mm}$ (R CL $300 \mathrm{~mm}$ ) can be seen in Figure 20. These percentages show that the strengthening of the $100 \mathrm{~mm}$ capping layer using plastic bottle waste geocells with a settlement in the thickness of the capping layer can be applied to road pavements that have low bearing capacity.

\section{Conclusion}

The results of this study were aimed to save the environment from the negative impacts of plastic bottle waste that damaged the environment on land, sea, and air pollution due to the burning of plastic waste. The results of the analysis using Plaxis showed that the geocell of plastic bottle waste could increase the bearing capacity up to $11,94 \%$. This could be an alternative to increase the efficiency up to $65 \%$ by reducing capping layer thickness. Therefore, geocells from plastic bottle waste could provide a solution to save granular materials, which consequently reduce the transportation cost of materials from quarries to project site and as an alternative for plastic bottle waste management to prevent the environment pollution.

Acknowledgment is presented to Dr. Eng. Fikri Faris for his trust in providing the opportunity to complete this manuscript, also to Prof. Hary Christady Hardiyatmo who has provided many inputs and the Department of Civil and Environmental Engineering, Gadjah Mada University.

$\begin{array}{ll}\text { List of symbols } \\ q_{u} & \text { ultimate bearing capacity }\left(\mathrm{kN} / \mathrm{m}^{2}\right) \\ P_{u} & \text { maximum load }(\mathrm{kN}) \\ A & \text { plate area or foundation }\left(\mathrm{m}^{2}\right) \\ B C R & \text { bearing capacity ratio } \\ q_{r} & \text { bearing capacity value without geosynthetic } \\ & \text { reinforcement }\left(\mathrm{kN} / \mathrm{m}^{2}\right)\end{array}$

$q_{o} \quad$ bearing capacity value in the presence of geosynthetic reinforcement $\left(\mathrm{kN} / \mathrm{m}^{2}\right)$

$E_{g} \quad$ young's modulus of the geocell-reinforced soil $\left(\mathrm{kN} / \mathrm{m}^{2}\right)$

$\sigma_{3} \quad$ confining pressure $\left(\mathrm{kN} / \mathrm{m}^{2}\right)$

$K_{e} \quad$ young's modulus parameter of the unreinforced soil $\left(\mathrm{kN} / \mathrm{m}^{2}\right)$

$M \quad$ line of intersection of the geocell material modulus $(\mathrm{kN} / \mathrm{m})$

$\gamma_{\text {unsat }} \quad$ unsaturated soil $\left(\mathrm{kN} / \mathrm{m}^{3}\right)$

$\gamma_{\text {sat }} \quad$ saturated soil $\left(\mathrm{kN} / \mathrm{m}^{3}\right)$

$\phi \quad$ friction angle $\left({ }^{\circ}\right)$

$v \quad$ poisson's ratio of soil

$\psi \quad$ angle of dilatancy $\left({ }^{\circ}\right)$

$C \quad$ cohesion of soil $\left(\mathrm{kN} / \mathrm{m}^{2}\right)$

$E \quad$ young's modulus $\left(\mathrm{kN} / \mathrm{m}^{2}\right)$

\section{References}

1. O. Alabi, K. Olagbonjaye, O. Awosolu, O. Alalade, Toxicol Risk Assess. 5, 1 (2019)

2. P. Purwaningrum. JTL. 8, 141-147 (2016)

3. Y. Sofiana, Humaniora. 1, 331-337 (2010)

4. Dhane, D. Kumar, A. Priyadarshe. Geocell : an emerging technique of soil reinforcement in civil engineering field, IOSR-JMCE, in Nasional Converence on Advances in Engineering, Technology \& Management (2015)

5. Krishna, A. Biswas, Geocell reinforced fondations, in training course on introduction to geosynthetics and their applications, December 142015 NIT Surat India (2015)

6. S.K. Dash, N.R. Krishnaswamy, K. Rajagopal, Geotextiles and Geomembran. 19, 235-256 (2001)

7. J. K. Thakur, J. Han, S. K. Pokharel, R. L. Parsons, Geotextiles and Geomembran 35, 14-24 (2012)

8. A. Emersleben, N. Meyer, Bearing capacity improvement of gravel base layer in road constructions using geocell, in International Association for Computer Methods and Advances in Geomechanics IACMAG, 1-6 October 2008, Goa India (2008)

9. A. Hedge, T.G. Sitharam, Geotextiles \& Geomembran 43, 171181 (2015)

10. H.C. Hardiyatmo, Fondasi I, Edisi 4 (Gadjah Mada University Press, Yogyakarta, 2020)

11. H.C. Hardiyatmo, Geosintetik untuk rekayasa jalan raya, edisi 2 (Gadjah Mada University Press, Yogyakarta, 2015)

12. I. Mehdipur, M. Ghazavi, R. Ziaie, Geotextiles \& Geomembran, 37, 23-34 (2013)

13. H. C. Hardiyatmo, Perancangan perkerasan jalan \& penyelidikan tanah, edisi 2 (Gadjah Mada University Press, Yogyakarta, 2015)

14. SNI (1725:2016). Pembebanan Untuk Jembatan, 39 (2016)

15. Manual Desain Perkerasan (Revisi 2017). Kementrian PUPR, 7-10 (2017) 